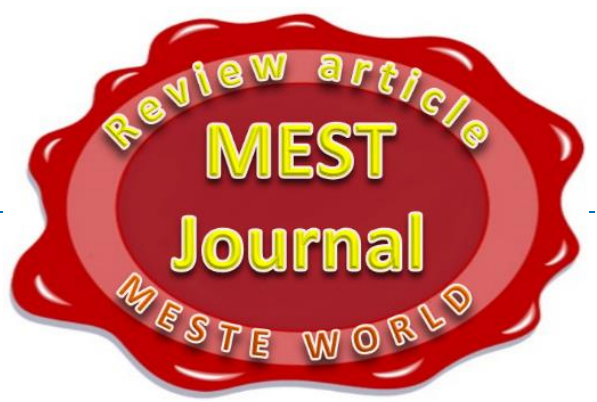

\title{
SOCIAL INNOVATIONS IN THE ECONOMIC INTEGRATION PROCESS - SELECTED ASPECTS
}

\author{
Agata Szydlik-Leszczyńska \\ Uniwersytet Jana Kochanowskiego w Kielcach, Poland \\ Marek Leszczyński \\ Uniwersytet Jana Kochanowskiego w Kielcach, Poland
}

(C) MESTE NGO

JEL category: F02, F15, F36

\begin{abstract}
The present-day stage of socio-economic development, on the one hand, encourages a strong economic integration of individual economies, but on the other, highlights the differences in economic, social and cultural potentials between countries and geographical territories (regions). One of essential conditions for achieving a high degree of convergence and cohesion is generating the background for a social change, which will result in releasing innovation, creativity and the ability to cooperate and compete. Modern-day economic development tends to concentrate on non-material resources including especially knowledge, technology and all varieties of innovations. The search for possibilities of meeting various social needs requires a certain combination of resources so that they are effectively used and competitive advantages are easily identified. A key issue is not only looking for the latest technological advances but also such social changes that will become a catalyst for development and will bring on positive effects in terms of an increase in society's well-being as well as contribute to solving many a social issue which are of interest to social politics. The following article touches upon the significance of social innovation for building up the basis for intensive socio-economic coordination (convergence) which takes territorial aspect into account. The following article touches upon the role of social innovations seen as a catalyst for social and economic change, which is supposed to favor achieving a high degree of economic convergence, in a gradual elimination of developmental differences.
\end{abstract}

Keywords: social innovations, convergence, territory, globalization

\section{SOCIAL INNOVATIONS - TERRITORIAL PERSPECTIVE}

The present-day stage of socio-economic development, on the one hand, encourages a

Address of the corresponding author:

Agata Szydlik-Leszczyńska

莑三”] a_szydlik-leszcynska@o2.pl strong economic integration of individual economies, but on the other, highlights the differences in economic, social and cultural potentials between countries and geographical territories (regions). In literature as well as in practical activities in the developmental politics, more and more frequently a territorial (regional) approach is being adopted. This raises a question on how similar specific regions are in terms of 
economic, social, special and cultural entities, and whether or not, it is possible to eliminate those differences and lay the foundations for a stable social development on an interregional and international scale. One of essential conditions for achieving a high degree of convergence and cohesion is generating the background for a social change, which will result in releasing innovation, creativity and the ability to cooperate and compete. The following article touches upon the significance of social innovation for building up the basis for intensive socio-economic coordination (convergence) which takes territorial aspect into account.

Modern-day economic development tends to concentrate on non-material resources including especially knowledge, technology and all varieties of innovations. The search for possibilities of meeting various social needs requires a certain combination of resources so that they are effectively used and competitive advantages are easily identified. A key issue is not only looking for the latest technological advances but also such social changes that will become a catalyst for development and will bring on positive effects in terms of an increase in society's well-being as well as contribute to solving many a social issue which are of interest to social politics.

Traditionally, the perception of innovation focused on its technical side. While on the subject of innovations, one thought mainly of new products, processes or technologies, less frequently of organization. These days' social innovations are more and more often perceived as a phenomenon or process which constitutes a total sum of social changes that are indicators of progress and modernization. These changes in a synergetic manner complete and interdepend on the process of technological changes. Social changes can give a new shape to labor market (including new forms of employment such as home office), can create new types of social bonds, e.g. generating social network society, and can streamline the processes of management and interpersonal communication. However, these changes can also lead to controversial social issues that interfere with human culture such as in vitro fertilization, homosexuality and manipulating human's biological sphere. The essence of innovation is inventiveness that promotes changes and progress, but it needs to be stressed that not every innovation brings benefits for human beings. That primarily depends on making man the focal point of the innovation process. As A. Nowakowska rightly states ' $(.$.$) the need for inventing new$ concepts and innovative ideas requires more intellectual powers, wider knowledge and creativity. As in many evolutionary processes, here one can observe a self-driven, cumulative process of changes which eventually resulted in crediting knowledge and innovation with a reputation of an independent and elementary productive factor. Consequently, modern-day economy is called an economy based on knowledge, where 'soft' factors have become the main driving force behind the socio-economic development' (Nowakowska, 2011, p. 31). A prerequisite for innovation to take place is the existence of a knowledge of specific 'gravity', then one can speak of forming 'innovation environment'. Innovation environment, according to D. Maillat, is a territorial entity from which the innovation process stems. There must be a definite type of interaction between economic subjects, public authorities and social sphere, which brings about certain external results (Nowakowska, 2011). Characteristics of innovation environment include: specific territorial boundaries viewed as the effect of collective processes of interaction, learning and adaptation -a collective product of the socio-economic sphere along with its organizational structure which facilitates the circulation of knowledge around the social network system, institutional and individual forms of activity and social mobility; learning dynamics illustrated by abilities and willingness on the part of all participants of the development process to make rapid changes and react to environmental dynamics and, consequently, suitably adjust their own actions to those requirements (Chadzynski, Nowakowska, \& Przygodzki, 2008). Needless to say, a crucial background as well as a generator of all sorts of innovation are growing globalization processes. Globalization itself can be described as: 'an ongoing long-term process of integration between an increasing number of national economies regardless of their borders, which takes place thanks to expanding and intensifying mutual connections (in investment, production, trade and cooperation areas). As a result, a worldwide economic system is emerging. This system is characterized by significant interdependence and 
considerable repercussions affecting even faraway countries. While describing the phenomenon of globalization, it is necessary to highlight the significance of liberalization of the world's economy, strengthening international connections, facilitation in the exchange of goods, services, capital, and technology and decreasing freight costs (Chmielewski, Lazniewska, \& Nowak, 2012). It must also be mentioned that the liberalization of economy brings about certain social costs that could be called 'modernization costs' or 'adaptation costs'. Globalization not only enforced innovation processes, but also led to redefining a nation-state into the one that fulfils a variety of social functions.

In his book Authority and Counter-Authority in a Global Era. New Economy of International Global Politics Ulrich Beck presents the diagnosis of the nation-state, the rationale behind its enfeeblement and the state's transformations. He states 'in a cosmopolitan constellation, the old nation-state transforms into the competitive market neo-liberal state, where politics follows the logic of capital (...) The likelihood of conversion of the nation-state into the neo-liberal state increases along with imposing some discipline on the state according to the rules of global economy, which bears some resemblance to the taming with a whip-like threat of credit refusal by IMF' (Beck, 2005, p. 325). A remedy for 'the world's maladies' is supposed to be, as the mainstream world's politics suggests, even more market economy and private capital which, while aiming for maximal effectiveness and productivity, will solve problems and dilemmas of ineffective and bureaucratic national mechanisms. Hence, the inefficient 'machine of state' is to be replaced by 'a perfect machine' of trans-national capital'. Such simplistic schemes meet with strong objections of (among others) Ulrich Beck who states ' $(. .$.$) the neo-liberal state is a perfect$ example of internationalization of the nation-state. Rigidly sticking to the neo-liberal credo (but not renouncing the nationalistic rhetoric), reformers and modernizers not only build the partition of the welfare or protective state, but also concur to the self-internationalization of the nation-state. In essence, it is the national autism that creates the necessary conditions for the state to make as a principle of its actions a three-fold rule: deregulation, liberalization and privatization, which makes fundamental reconstruction happen behind the now-empty pretense of the nationstate. It is a textbook example of active selfdisassembly taking place along with a strong emphasis being put on the fact that there are no alternatives to the actions subordinate to the logic of capital. [...]Authorities assessing credit rating scrutinize if companies, countries and local communities behave 'appropriately', i.e. according to the rules of neo-liberal prudence. At the beginning of the 21st century the International Monetary Fund monitors at least one third of sovereign countries of the world.' (Beck, 2005, pp. 325-326) Speaking of the globalization and liberalization process one must point to the factors that contribute to the success or failure of particular territories and their inhabitants. Therefore, apart from areas of innovation, welfare and social development there are also areas of long-lasting economic backwardness with the deteriorated quality of life. Surely the human and social capital accumulated over a certain area acts as crucial stimulus to innovation (including social innovation) (See: Bourdieu (1986), Becker (1975), Bartoszek (2008), Karwinska (2008).

Innovation area or innovation environment ought to fulfil the following main characteristics (Chadzynski, Nowakowska, \& Przygodzki, 2008):

- a spatial set, i.e. a geographic region with literally no boarders although representing a unity expressed in idiosyncratic identifiable behaviors

- a set of actors: entrepreneurs, research institutions, educational institutions, public authorities, qualified personnel, who should be characterized by decision-making independence and the ability to create social reality

- -specific material resources (firms, infrastructure), institutional resources together with abilities, culture and a set of rules,

- -the organizational logic (the capability to cooperate), which aims for the best use of commonly created resources by interdependent subjects willing to satisfy the needs of one another,

- the learning logic, a certain capacity to change, which depends on the ability of particular subjects to alter their behavior according to the transformation of market- 
based, technological and informational environments.

Hence, there has to exist a phenomenon called innovation environment. A. Jewtuchowicz (2005) calls in this way the existence of common phenomena making a particular territory distinctive. "(...) the main criterion is two features essential for the existence of the environment, i.e. the ability to cooperate and the capability to learn. The ability to cooperate, demonstrated in the organizational logic, should be linked with the capacity for the competitive behavior.

The measure of the organizational logic is closeness and intensity of relations between actors, whereas the learning logic is expressed through the actors' ability to simultaneously modify their behaviors, depending on the internal changes in the system and also changes in their environment."

\section{THE PROCESS OF ECONOMIC AND SOCIAL INTEGRATION (CONVERGENCE)}

Economic convergence is a process of unification of economies of various states, regions or functional areas due to their substantial attributes. There is no unequivocal or generally accepted definition of convergence, one can only point to various aspects or characteristics that are prerequisite for the above-mentioned similarities. Consequently, one can speak of compatibility of economic growth, convergence of financial systems or markets, similarity of models of capitalism, standardization of lifestyles and models of consumption and homogeneity of governance styles in the public sector (public administration). Thus, there is no one -holistic approach to convergence in the countries compared (Jablonski, 2012). On account of integration of economic and social studies in the research on the nature of social changes and the processes taking place in the post-modern, era it is legitimate to distinguish a number of crucial spheres in human activity; each sphere serves a different purpose (Jablonski (2012, p. 13), Wozniak (2005, p. 173)):

- economic and consumption sphere, related to the level and structure of consumption, income and per capita productivity, country's economic maturity, well-established system of state institutions which guarantee individual's rights (property rights, the right to live, freedom, mobility and other)

- biological and natural sphere, which comprises biological conditions under which life exists, life expectancy, the quality of the environment

- intellectual sphere, reflected by the standards of knowledge (level and structure of country's education), technology (the advancement of Research and Development sector)

- spiritual and social sphere, including axiological system, well-established and recognized moral values, behavioral patterns, ethics and non-standard social norms

- political sphere.

"Convergence of the regulatory sphere in individual countries can be considered in the light of legal order and commonly recognized and acceptable norms, patterns, social, ethical, religious and familial values, which shape socioeconomic processes. Consequently, this type of convergence can be understood as a process of countries becoming similar to one another in terms of functioning socio-economic institutions" (Jablonski, 2012, p. 16). The concept of convergence is described whereby a variety of indexes which come to use when global comparisons are made. The most popular index (measure) is GDP, but it mainly reflects the production volume, not the wealth itself and it fails to take social factors into account. For the sake of comparison, alternative measures of wealth have been suggested. They go further beyond market transaction value, including social development index (HDI), sex-related social development index (GDI) and poverty index (HPI). There also exist synthetic measures of wealth depended on economic sphere, which adjust the GDP value according to the level of costs resulting from the economic growth. This group of measures include above all: measure of economic wealth (MEW), measure of national net wealth (NNW) or general progress index (GPI). While on the subject of socio-economic development indexes, one should pay special attention to measures of institutional development in that country's institutional maturity and its ability to fulfil social functions are vital for the high standard of living of its citizens. The above-mentioned measures "reflect determinants 
resulting from legitimized official market-economy institutions which enable national and foreign entrepreneurs to be active and increase economic wealth (Jablonski, 2012, p. 54)". In the light of economic wealth and institutional order, there are two significant measures: of economic freedom and of economic competitiveness. Achieving a high degree of institutional efficiency is dependent on two components: observing political rights and civil rights. Within political rights one can name three elementary measures: the election process (freedom and equality of the vote for the central authorities in the state), social participation (determining the right to unite in socio-political parties, to form political opposition and to hold political views free from any pressure from totalitarian parties, religious hierarchy, military forces or other countries), fully operational central government (representatives elected in independent elections can freely shape the government policies, corruption levels, the open nature of operations, and trust that society put in their government. Civil rights are measured with four indexes: the index for freedom of speech and views (this index is made up from freedom and independence of the media, religious freedom, religious observances, education system free from any political influences, the index for the right to unite in associations and organizations (determining the right to gather, demonstrate and hold a debate in public, the right for free functioning of non-governmental organizations, trade unions and other organizations), the index for the legal rule ( reflecting the independence and sovereignty of the courts of law, protection against political terror, unjustified and unlawful arrest and equality of all citizens before law and politics), the index for autonomy and individual rights (describes the equal opportunities and treatment of both sexes, the right to run one's own business and the extent to which the state is allowed to have control over its citizens' mobility, place of residence, employment and education (Jablonski, 2012).

\section{CONCLUSIONS}

Achieving a high degree of rapprochement between different territories in their socioeconomic development, a high degree of convergence, requires, on the one hand, the existence of premises in an economic sphere, raising its innovativeness, efficiency and competitiveness, but on the other, it needs specific social changes which will lead to ICT society able to operate and think creatively. Modernizing the system of holding public power requires, in turn, introducing some elements of task-oriented public management which heavily relies on a costeffectiveness principle. Creating the right atmosphere for the desired changes is subjected to the society that functions along with competition and trust rules and that is able to make a cooperation network and the society of high developmental potential which cumulates human and social capital in itself.

\section{WORKS CITED}

Bartoszek, A. (2008). Konwersja kapitałów społeczno-kulturowych na kapitał obywatelski. Katowice : Wydawnictwo Uniwersytetu Ślaskiego.

Beck, U. (2005). Władza i przeciwwładza w epoce globalnej. Nowa ekonomia polityki światowej. Warszawa: Scholar.

Becker, G. (1975). Human capital: a theoretical and empirical analysis with special reference to education. New York: National Bureau of Economic Research. Retrieved from http://www.nber.org/chapters/c3730.pdf

Bourdieu, P. (1986). Handbook of Theory and Research for the Sociology of Education: The Forms of Capital. (J. Richardson, Ed.) New York-London: Greenwood.

Chadzynski, J., Nowakowska, A., \& Przygodzki, Z. (2008). Region i jego rozwoj w warunkach globalizacji. Warszawa: Cedewu.

Chmielewski, R., Lazniewska, L., \& Nowak, P. (2012). Globalizacja, neoliberalizm i nowy region, (in:) Konkurencyjnosc regionalna. (E. Łaźniewska, \& M. Gorynia, Eds.) Warszawa: PWN.

Jablonski, L. (2012). Kapital ludzki a konwergencja gospodarcza. Warszawa: CH Beck. 
Jewtuchowicz, A. (2005). Terytorium i współczesne dylematy jego rozwoju. Łódź : UŁ.

Karwinska, A. (2008). Budowanie kapitału społecznego we współczesnej Polsce. Czynniki stymulujace i bariery. In M. S. Szczepański, K. Bierwiaczonek, \& T. Nawrocki, Kapitały ludzkie i społeczne a konkurencyjność regionów (pp. 111-126). Katowice: Wydawnictwo Uniwersytetu Slaskiego.

Nowakowska, A. (2011). Regionalny wymiar procesów innowacji. Lodz: UL.

Wozniak, M. (2005). Kapital ludzki i intelektualny w strategii pro wzrostowej ograniczajacej nierownosci spoleczne. Rzeszow: Uniwersytet Rzeszowskiego.

Received for publication: $\quad 23.01 .2014$

Revision received: $\quad 27.05 .2014$

Accepted for publication: $\quad 23.06 .2014$

How to cite this article?

Style - APA Sixth Edition

Szydlik-Leszczynska, A., \& Leszczynski, M. (2014, 07 15). Social innovations in the economic integration process - selected aspects. (Z. Čekerevac, Ed.) MEST Journal, 2(2), 121-126. doi:10.12709/mest.02.02.02.13

Style - Chicago Fifteenth Edition:

Szydlik-Leszczynska, Agata, and Marek Leszczynski. 2014. "Social innovations in the economic integration process - selected aspects." Edited by Zoran Čekerevac. MEST Journal (MESTE) 2 (2): 121-126. doi:10.12709/mest.02.02.02.13.

Style - GOST Name Sort:

Szydlik-Leszczynska Agata and Leszczynski Marek Social innovations in the economic integration process - selected aspects [Journal] // MEST Journal / ed. Čekerevac Zoran. - Belgrade : MESTE, 07 15, 2014. - 2 : Vol. 2. - pp. 121-126.

Style - Harvard Anglia:

Szydlik-Leszczynska, A. \& Leszczynski, M., 2014. Social innovations in the economic integration process - selected aspects. MEST Journal, 15 07, 2(2), pp. 121-126.

Style - ISO 690 Numerical Reference:

Social innovations in the economic integration process - selected aspects. Szydlik-Leszczynska, Agata and Leszczynski, Marek. [ed.] Zoran Čekerevac. 2, Belgrade : MESTE, 07 15, 2014, MEST Journal, Vol. 2, pp. 121-126. 